УДК 35.071.6:005.591.4

DOI: 10.34132/pard2020.10.07

\title{
РИЗИКИ РЕФОРМИ ДЕЦЕНТРАЛІЗАЦІЇ ТА СПОСОБИ ЇХ ВИРІШЕННЯ
}

Смельянов B.M., д-р наук 3 держ., упр., професор, Інститут державного управління, Чорноморський національний університет ім. Петра Могили, м. Миколаїв, Україна.

Сокирко M.C., аспірант Інститут державного управління, Чорноморський національний університет ім. Петра Могили, м. Миколаїв, Україна.

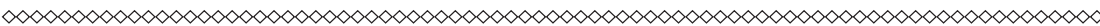

Статтю присвячено, аналізу можливих ризиків реформи децентралізації та пошуку шляхів їх вирішення $i$ зменшення. Перебуваючи в незавершеній стадіï, децентралізація є важливою системною перебудовою, від наслідків якої, залежать безпека, розвиток та економічний підйом на місчевому, а також загальнодержавному рівні. Системні зміни на місиевому рівні в умовах економічної та політичної нестабільності, потребують обережної та виваженої державної політики. Виявлено основні ризики, які загрожують проведенню реформи та становлять небезпеку суверенітету України, сепаратизму, відиентрових тенденцій, анклавізації, криміналізації. Особливим ризиком можливий сепаратизм в окремих регіонах держави. Нестабільна політична ситуачія, як на загальнодержавному, та особливо на місиевому рівні, загрожує реформі децентралізації та ефективності роботи місиевої влади. Досліджено питання мовного та етнонаціонального чинників та їх роль у процесі формування об'єднаних громад. Методологічний та нормативний порядок організації децентралізації, має важливе значення та зв'язок $з$ реальним станом об 'єднання громад. Проаналізовано запропоновані внесення змін до Конституції України стосовно децентралізації та 
їхні ризики. Законність та верховенство права є необхідною умовою для попередження ризиків децентралізачії, а також забезпечення розвитку об'єднаних громад. Розглянуто роль префектів у нагляді за законністю рімень органів місиевого самоврядування з можливістю не порушення функиіонального балансу судової гілки влади. Запропоновано, можливі попереджувальні иляхи зменшення ризиків та викликів реформи, вирішення актуальних питань реформи, а також сприяння державотворенню. У роботі досліджено мовне питання національних меншин, а також висловлено думку про важливість державної мови як об'єднуючого та державотворчого чинника.

Ключові слова: децентралізація, дезорганізація, нагляд, префект, культура, етнонаціональний, мова, закон.

Постановка проблеми у загальному вигляді. Реформа децентралізації наразі $€$ однією 3 найуспішніших реформ в Україні. Децентралізація сприймається як процес передачі повноважень від органів державної влади органам місцевого самоврядування, можливість громад розпоряджатися власними доходами та ресурсами, підвищення якості та доступності послуг для громадян. Водночас реформа децентралізації окрім переваг для функціонування місцевого управління має значні виклики, пов'язані з системними змінами на місцевому рівні. Враховуючи політичну, економічну, соціальну нестабільність, в умовах зовнішньої агресії, децентралізація може призвести до посилення негативних тенденцій на місцевому рівні, які здатні вплинути на подальший розвиток держави. Для впровадження реформи децентралізації потрібно враховувати можливі ризики які здатні завадити реформі та розробити механізми їх запобігання для успішного проходження реформи. На шляху реалізації процесу децентралізації знаходиться низка викликів в етнокультурній, управлінській сферах, законності та правопорядку, а також загроза порушення суверенітету. 
Необхідно враховувати можливі мінуси та виклики її проведення для того, щоб децентралізація не перетворилася в дезорганізацію.

Замість ефективноїдецентралізації, може відбутисяпослаблення державної влади та посилення впливу окремих регіонів, що може негативно вплинути на функціональні можливості держави, в тому числі і наповнення місцевих та державного бюджетів. Виникає ризик посилення нерівномірного територіального розвитку.

Можлива регіоналізація, тобто посилення місцевих еліт, політичних монополій які контролюють ресурси громад. Децентралізація має забезпечити передачу повноважень 3 адміністративного центру на місця, але, при цьому не повинна призводити до утворення фрагментованих державних утворень.

В умовах реформи децентралізації необхідним є створення ефективної системи нагляду і контролю над органами місцевого самоврядування щодо законності їхньої діяльності. Тому, від ефективної роботи судової і правоохоронної систем залежить законність та правопорядок діяльності органів місцевого самоврядування. 3 передачею адміністративних повноважень та збільшенням місцевих бюджетів необхідним є механізм запобігання корупції місцевої влади.

В процесі децентралізації важливо враховувати етнонаціональні чинники територіальних громад, а також запобігати утворенню ізольованих анклавів тієї чи іншої національної меншини. Постійні зміни у законодавстві викликають нестабільність та недовіру до реформи. Недостатня поінформованість про реформу перешкоджає іiі реалізації, створює основу для міфів та маніпуляцій.

Для ефективного управління та використання адміністративних ресурсів потрібні управлінці базового рівня які мають відповідну кваліфікацію. Брак кваліфікованих кадрів та менеджерів може суттєво вплинути на проходження реформи децентралізації.

Аналіз останніх досліджень і публікацій. Децентралізація як системне явище знайшла своє відображення в працях вітчизняних науковців, таких як: В. Смельянов, А. Шульга, О. Свтушенко, В. Андріяш, Т. Гладка, Л. Клівіденко, О. Скрипнюк., Т. Тарасенко, C. Квітка. В працях цих науковців приділялася увага як загальному 
аналізу становлення місцевого самоврядування у процесі децентралізації, а також ризикам та викликам децентралізації, необхідності дотримання методологічного порядку та вироблення законодавчої бази. Досліджувалися етнонаціональні чинники та їхній вплив на об'єднані громади. В економічному аспекті бюджетна децентралізація розглядається в працях Н. Македонської Досліджено також електронні публікації з проблем децентралізації фахових експертів, державних діячів.

Формулювання цілей статті (постановка завдання). Під час дослідження були визначені наступні завдання:

- окреслити можливі ризики проходження реформи децентралізації та передбачити їх наслідки;

- запропонувати необхідні рішення спрямовані на пом'якшеня та подолання цих ризиків для успішного завершення реформи децентралізації;

- розглянути запропоновані зміни до Конституції України стосовно децентралізації та наслідки їх впровадження;

- дослідити питання статусу державної мови та іiі співвідношення з мовами національних меншин;

- визначити способи міжкультурної взаємодії різних етнічних груп громад.

Виклад основного матеріалу дослідження. Зпочатком реформи децентралізації виникає дієвий і спроможний інститут місцевого самоврядування - об'єднані територіальні громади. Новостворені територіальні громади беруть на себе відповідальність за всі сфери життєдіяльності громади на своїй території. Ефективність реалізації поставлених перед територіальними громадами завдань є основним показником успішності даного об'єднання та реформи загалом. Децентралізація відкриває значні перспективи для забезпечення спроможності органів місцевого самоврядування самостійно вирішувати питання місцевого рівня, зокрема через підвищення ролі громадян, їх впливу на процес прийняття рішень та втілення рішень [1, с. 5].

Разом 3 відповідальністю об'єднаних територіальних громад, 
виникає також і схильність їх до певних ризиків за відсутності необхідних важелів стримувань для запобігання зловживанням та правопорушенням.

Децентралізація тісно пов'язана 3 організацією системи державного управління. На нашу думку, місцева влада у формі об'єднаних територіальних громад спроможна існувати виключно за демократичної форми правління на місцях. Місцева, або (муніципальна) демократія включає:

$>$ громадянське суспільство, активно спрямоване на вирішення місцевих питань;

$>$ механізм погодження інтересів між державою та об'єднаними громадами;

відносини на засадах рівноправності та партнерства між владою та населенням громад [40, с. 9-10].

Вона сприяє побудові ефективних взаємовідносин між центральним урядом й органами управління на локальному рівні. У зв’язку з цим виникає загроза прийняття місцевою владою рішень, які не відповідають інтересам громад або порушують національні інтереси у питаннях безпеки, мовної політики, європейської інтеграції тощо, за відсутності належного контролю 3 боку центральних органів влади та правоохоронних структур.

Організація та створення належного функціонування судової та правоохоронної систем $€$ важливим чинником від якого залежить реформа децентралізації та законність прийняття рішень органами місцевого самоврядування. Неефективна або відсутня система державного нагляду за законністю прийняття рішень місцевими органами влади, а також, неефективна судова i правоохоронна система можуть призвести до прийняття місцевою владою рішень, які порушують законодавство, інтереси об'єднаних громад, що негативно вплине на результати реформи та місцеву владу [6, с.12].

Зі збільшенням повноважень органів місцевого самоврядування виникає ризик корупції на місцевому рівні. Розгляд земельних питань часто відбувається без належної прозорості та звітності. Особливої актуальності цей ризик набуває у зв'язку із проведенням 
земельної реформи, переміщенням закупівель землі на рівень місцевих органів влади.

Можливість дезавуювати цей ризик полягає у збільшенні прозорості прийняття рішень місцевою владою, що включає: оприлюднення рішень місцевих рад, протоколів виконавчих комітетів, інформацію про засідання депутатських комісій, а також інформація про всі події та заходи за участі місцевої влади.

Водночас, необхідним є оприлюднення у відкритому доступі на веб-сайтах містобудівних кадастрів, геоінформаційних сервісів, геодезичної інформації запровадження електронної системи закупівель, земельних аукціонів, а також запровадження системи безконтактних (електронних) адміністративних послуг, розвиток центрів надання адміністративних послуг у громадах [33, с. 10].

Р. Безсмертний, В. Смельянов та інші дослідники, сприймають децентралізацію скоріше як експеримент, а не як реформу, оскільки проведенню реформи має передувати розроблення законодавчої бази. Так науковець В. Смельянов поділяє думку Р. Безсмертного який зазначає про неможливість проведення таких змін без внесення відповідних поправок до Конституції, до законів про місцеве самоврядування та Бюджетного кодексу [19].

Варто відмітити, що на сьогоднішній день, ані конституційних змін, не впровадження посадової особи префекта не існує. Подальше просування реформи територіальних громад без змін до конституції може суттєво підірвати керованість державою. На сьогоднішній день, ми маємо приклади того, як приймаються рішення обласними територіальними громадами всупереч діючому законодавству. До прикладу, Тернопільська обласна рада, всупереч прийнятому закону «Про державне регулювання діяльності щодо організації та проведення азартних ігор», який визначає організаційно-правові та економічні умови проведення азартних ігор, прийняла рішення про заборону грального бізнесу на території області [32].

Для забезпечення законності та правопорядку органів місцевого самоврядування, реформа децентралізації потребує відповідного нагляду за законністю прийняття рішень. На сучасному етапі у зв’язку з відміною прокурорського нагляду це питання набуває 
особливої актуальності.

Можливість створення альтернативного нагляду за законністю, вперше була передбачена у Постанові Верховної Ради України «Про попереднє схвалення законопроекту про внесення змін до Конституції України, щодо децентралізації влади» від 31.08. 2015 р. [2].

Даною Постановою було передбачено, можливість здійснення нагляду за законністю рішень місцевого самоврядування новою майбутньою посадовою особою, а саме префектом. Однією 3 найважливіших функцій префекта $\epsilon$ здійснення нагляду за дотриманням органами місцевої влади законності у прийнятті рішень та недопущення порушення законодавства.

Так ст. 144 цієї постанови, передбачалось право префекта зупинити дію актів місцевого самоврядування, через їх невідповідність Конституції чи іншим законам України, а також звернутися до суду. Відповідними повноваженнями 3 нагляду за законністю рішень органів місцевого самоврядування планувалося наділити Президента та тимчасового державного уповноваженого [2].

Відповідний порядок здійснення нагляду передбачає, що у випадку ухваленням одним 3 органів місцевої влади акту, який суперечить Конституції України, загрожує державному суверенітету, територіальній цілісності та національній безпеці, президент України повинен зупинити дію відповідного акту та звернутися до Конституційного Суду України, а також тимчасово зупинити повноваження відповідного органу та призначити тимчасового державного уповноваженого, для організації діяльності виконавчого органу місцевої влади.

У постанові також передбачалось координація префектом діяльності територіальних органів та центральних органів виконавчої влади, здійснення нагляду за додержанням ними Конституції і законів України; забезпечення виконання державних програм; спрямування та організацію діяльності територіальних органів, центральних органів виконавчої влади та забезпечення їх взаємодії 3 органами місцевої влади в умовах введення воєнного, надзвичайного стану, надзвичайної екологічної ситуації. Передбачалась можливість глави держави тимчасово зупиняти 
здійснення повноважень органів місцевої влади, якщо вони призводять до загрози державному суверенітету [2].

Нормативно-правове забезпечення організації процесу децентралізації є надзвичайно важливою складовою, яка впливає на реалізацію реформи місцевої влади та сприяє подоланню багатьох ризиків. Конституція України являє собою юридичну основу всього законодавства держави, Основний закон, який регулює державний устрій, місцеве самоврядування та є базою для прийняття всього законодавства щодо реформування місцевої влади. Для успішного проведення реформи децентралізації необхідні системні зміни до Основного закону України які повинні сприяти досягненню цієї мети [3, с. 2].

У грудні 2019 року на розгляд Верховної Ради України президентом України був внесений проект закону № 2598 від 13.12.2019 «Про внесення змін до конституції України щодо децентралізації влади», спрямований на створення конституційної основи для децентралізації влади в Україні та посилення правового статусу місцевого самоврядування [31].

Основні положення даного законопроекту передбачали:

1) первинною одиницею адміністративно-територіального устрою є громада, яка створюється на основі спільних історичних, етнічних, культурних традицій, демографічних особливостей, враховуючи географічне розташування та економічні зв'язки, традицій, а також грунтується на засадах єдності та цілісності території громад, децентралізації, спроможності місцевого самоврядування до вирішення питань місцевого значення, розвитку адміністративних одиниць.

2) повноваження між органами місцевого самоврядування та їх виконавчими органами відповідного рівня, розмежовуються та здійснюються за принципом субсидіарності, згідно 3 яким, наділення повноваженнями органу, відбувається відповідно до обсягу і характеру завдань, а також вимоги досягнення ефективності та економії, що відповідає Європейській хартії місцевого самоврядування.) $[15$, с. 2$]$.

3) ліквідація місцевих державних адміністрацій та скасування 
інституту голови місцевої державної адміністрації. Також, основні повноваження зосереджуються на місцевому рівні у громаді та передаються виконавчим органам рад відповідного рівня $[3$, с.3]. Передбачається утворення представницьких і виконавчих органів місцевого самоврядування.

4) утворюються виконавчі органи громад, які $є$ підзвітними відповідним радам громад;

5) закріплюється матеріальна i фінансова основа місцевого самоврядування, що являє собою землю, рухоме і нерухоме майно, природні ресурси, інші об'єкти, які належать громаді на праві комунальної власності, а також місцеві податки і збори, частину загальнодержавних податків та інші доходи місцевих бюджетів.

6) запроваджується інститут префекту як абсолютно нової посадової особи з особливими повноваженнями;

7) запровадження нової системи адміністративнотериторіального устрою трьох рівнів: області, району та громади 3 повсюдністю місцевого самоврядування[17, с. 6].

8) можливість визначення окремим законом порядку адміністративно-територіального устрою, що передбачає утворення, ліквідацію, найменування, перейменування, встановлення та зміни меж громад, округів та областей.

Запропонований проект закону, зазнав численної критики різних громадських організацій та небезпідставного занепокоєння західних партнерів України. Асоціація об'єднаних територіальних громад зазначає про необхідність обговорення законопроекту про внесення змін до Конституції, як підгрунтя децентралізації 3 представниками органів місцевого самоврядування. Оскільки він має низку зауважень тому вони занепокоєні щодо положень цього законопроекту.

Сама можливість зупиняти рішення місцевоївладиє невід'ємною функцією суду. У даному разі відбувається порушення балансу гілок влади та наділення префектів невластивим для них повноваженням. Ідея здійснення контролю за законністю префектом є правильною, але іiі реалізація потребує дотримання встановленого законодавчого порядку, що дозволить уникнути неправомірного впливу префектів 
та посилення корупції.

На думку експерта 3 децентралізації Р. Рохова «префект має бути представником держави в регіоні, також має бути дотриманий баланс повноважень різних гілок влади. Префект повинен бути представником держави в регіоні, при цьому, має відбуватися баланс контролю та функцій. У разі виявлення порушення конституції та законів у рішеннях органів місцевого самоврядування, префект повинен, спочатку написати листа до органу місцевого самоврядування 3 переліком проблем та часом на їх усунення, якщо вони не будуть усунені, звернутися до адміністративного суду з вимогою скасувати рішення на підставі його невідповідності закону» [24].

Таким чином, префект буде виконувати функцію контролю за законністю рішень органів місцевого самоврядування, не втручаючись у діяльність судової гілки влади та не порушуючи суддівську функцію зупинення рішення у разі його невідповідності законодавству.

На сьогоднішній день, місцеві влади чинять опір впровадженню інституту префектів через поширені міфи, щодо ролі префекта та його роботи. Поширеною є думка, що запровадження префектів, може призвести до централізації та зловживання повноваженнями. Важливо пам'ятати, що префект не втручається у діяльність органів місцевого самоврядування, а здійснює контроль через суд у законний спосіб. Префект повинен здійснювати тиск на органи місцевого самоврядування, а встановлювати відповідність рішень місцевих органів законодавству, таким чином здійснюючи захист інтересів громади.

Викликає сумнів та застереження зміни стосовно адміністративно-територіального устрою. Формулювання законодавчого врегулювання порядку створення, встановлення та зміни меж, найменування районів, громад та областей є особливо ризиковим в контексті визначення адміністративно - правового статусу тимчасово окупованих територій Донецької та Луганської області. Оскільки в даному випадку виникає ризик включення окупованих частин Донбасу до складу України на умовах 
«особливого статусу», що призведе фактично до федералізації та дестабілізації країни.

Внаслідок активної суспільної реакції та аналізу, даний законопроект був відкликаний президентом 16 січня 2020 р. та відправлений на доопрацювання.

Варто наголосити що сам процес реформи децентралізації розпочався у непослідовній формі, а саме 3 фінансової децентралізації. Хоча, першочергово, повинні були б розпочатися зміни меж адміністрування, передача повноважень на місця, і тільки після цього передача фінансів на виконання повноважень [24].

Дотримуючись методики формування громад, обласні ради мали б узгоджувати перспективні плани і в його межах провести консультації про створення громад, ухвалити рішення про їх створення, визнати громади спроможними та провести вибори.

Цілком логічно, що процесу формування об'єднаних громад повинно передувати розроблена законодавча основа, яка включає відповідні зміни до Конституції, прийняті нові Закони України «Про місцеве самоврядування» та «Про адміністративно-територіальний устрій», розроблена «Методика формування спроможних територіальних громад».

Слушно відмітити, що протягом 2014-2015 pp. було розроблено та прийнято низку законодавчих актів, які заклали основу для системних змін на місцевому рівні, серед яких зокрема є Закони України: «Про співробітництво територіальних громад» від 17.06.2014 р. № 1508-VII [37], «Про добровільне об’ єднання територіальних громад» від 05.02.2015 р. № 157-VII [5], «Про засади державної регіональної політики» від 05.02.2015 p. № 156-VIII [38], «Про ратифікацію Додаткового Протоколу до Європейської хартії місцевого самоврядування про право участі у справах органу місцевого самоврядування» від 02.09.2014 № 1664 -VII [39], зміни до Бюджетного [40] та Податкового [41] Кодексів, та інші [29, с. 2].

Дані закони визначають принципи основні засади, форми, та підстави співробітництва громад, основи регіональної політики, порядок добровільного об’ єднання громад, що включає: ініціювання 
об'єднання, підготовку рішень про об'єднання громад, утворення об'єднаної громади, форми державної фінансової підтримки та ін.

Проте, у зв’язку з прийняттям Закону України «Про об'єднані територіальні громади», раніше, ніж було затверджено методику формування спроможних територіальних громад та зважаючи на відсутні досі зміни до Конституції, формування об'єднаних громад відбувалося самостійно та без відповідної нормативно-правової бази, а також спираючись на матеріальні та політичні інтереси певних груп.

Постанова Кабінету Міністрів України «Про затвердження Методики формування спроможних територіальних громад» закріплює методичні рекомендації щодо того, як повинно відбуватися формування спроможних територіальних громад шляхом їх добровільного об'єднання. Відповідно до цієї Постанови, формування спроможних громад повинно здійснюватися шляхом розроблення, схвалення та затвердження перспективних планів [16].

Фактично, перспективні плани формування територіальних громад не $є$ реалізованими повною мірою, через недотримання територіальних меж, що були визначені при підготовці проектів об'єднання, відсутність грунтовного соціально-економічного аналізу рівня розвитку громад, неврахування культурно-етнічних й історичних особливостей громад, а також випадків не прийняття рішень обласними радами, щодо ухвалення перспективних планів.

Обласні ради не завжди вчасно та раціонально приймають рішення щодо схвалення перспективних планів формування територій громад областей, часто політизуючи цей процес 3 метою збереження свого впливу на потенційних виборців. В результаті, громади об'єднуються не залежно від перспективних планів, а в подальшому набагато простіше підлаштувати план під об'єднання громади а не об'єднання громади за планом. Більшість об'єднанних територіальних громад були створені поза межами розроблених перспективних планів.

При обласних державних адміністраціях були створені робочі групи, по розробленню і узгодженню з обласними радами, перспективних планів про створення об'єднаних територіальних 
громад, але як показує практика, і за згодою Мінрегіонбуду, почалося хаотичне створення ОТГ не за перспективними планами.

Станом на 01 жовтня 2019 року на приблизно 87,6\% території України були розроблені перспективні плани формування територій громад областей, які в більшості випадків неповністю враховували Методику формування спроможних територіальних громад [30]. Питання прийняття та затвердження перспективних планів потребувало прискорення.

У зв'язку з цим, Законом Про внесення змін до Закону України «Про добровільне об〉єднання територіальних громад» щодо спрощення процедури затвердження перспективних планів формування територій громад Автономної Республіки Крим, областей від 05.12.2019 [20], було доповнено частину першу статті 4 Закону України «Про об’єднання територіальних громад» вимогою, щодо здійснення процесу об’єднання, відповідно до перспективних планів формування територій громад, а також ч. 3 ст. 11 відповідно до якої, перспективний план формування територій громад затверджується Кабінетом Міністрів України за поданням відповідної обласної державної адміністрації.

Станом на 27 Травня 2020 року в Україні було затверджено 24 перспективні плани формування об'єднаних громад та утворено 1469 об'єднаних територіальних громад, що повністю покриває територію країни та фактично означає системнізміни адміністативнотериторіального устрою [36]. В подальшому очікується прийняття таких важливих законодавчих актів: «Про засади адміністративнотериторіального устрою України», «Про службу в органах місцевого самоврядування», оновліні закони «Про місцеве самоврядування», «Про місцеві державні адміністрації» та ін.

Спроможність територіальних громад є необхідною складовою успішного об'єднання громад. Відповідно до Методики формування спроможних територіальних громад, спроможною громадою $\epsilon$ громада, яка в результаті об'єднання здатна забезпечити надання своїм громадянам публічних послуг у таких сферах як освіта, культура, охорона здоров'я, соціальний захист, житлово-комунальне господарство, а також має достатньо кадрових ресурсів, фінансового 
забезпечення та здатна розвивати власну інфраструктуру [16].

Оцінка рівня спроможності відбувається на основі критеріїв соціально-економічних показників розвитку громади, таких як, чисельність населення громади, чисельність учнів закладів загальної середньої освіти на території громади, площа території, індекс податкоспроможності бюджету громади, частка місцевих податків і зборів [16].

Для підвищення спроможності громад необхідним є розробка програми соціально-економічного розвитку, розвиток малого та середнього бізнесу, план місцевого економічного розвитку. При об'єднанні громад потрібно приєднуватися до вже створених громад, які отримали повноваження, мають реальні результати, які свідчать про спроможність та успішність громади, як то відкриті центри надання адміністративних послуг, відремонтовані школи, спортивні майданчики, реалізовані міжнародні проекти та ін. [21].

Також вагомим внеском у спроможність громад були i залишаються державна підтримка в вигляді субвенцій $з$ державного бюджету місцевим бюджетам що вирішує соціально-побутові питання для комфортного проживання населення, таких як: капітальний ремонт та реконструкція шкіл, дитячих садків, придбання обладнання, реконструкція лікувальних корпусів лікарень, придбання медичного автомобіля; реконструкції сільських будинків культури, стадіонів; капітальний ремонту дорожнього покриття вулиць, провулків, проїздів, під’їдів, автодоріг; капітальний ремонт та реконструкція мережі вуличного освітлення, будівництво, реконструкція та облаштування системи водопроводу, розвідувально-експлуатаційних свердловин, водонапірних башт, придбання спецтехніки для комунальних, виготовлення містобудівної документації тощо.

Так, завдяки реалізації проектів за рахунок субвенцій 3 державного бюджету місцевим бюджетам підвищується громадська довіра до обраних ними органів та посадових осіб, що позитивно впливає на формування громадської самосвідомості жителів та на активізацію їхньої безпосередньої участі у вирішенні питань місцевого значення, активізується управлінська та господарська 
функції місцевої влади, крім того, все чіткішими та виразнішими стають практичні дії органів місцевого самоврядування стосовно забезпечення розвитку всіх населених пунктів, з яких сформувалася громада [43].

Заступник міністра розвитку громад та територій України В. Негода стверджує про необхідність чіткого розмежування повноважень органів державної влади та місцевого самоврядування за принципом субсидіарності, про що він зазначає: «Важливо спільно 3 кожним профільним міністерством найближчим часом ретельно попрацювати над секторальними повноваженнями. Паралельно будемо вести роботу 3 Міністерством фінансів, оскільки повноваження, ті, які делегує держава органам місцевого самоврядування, повинні бути забезпечені і фінансами для їх виконання». А також він стверджує: «в майбутньому новому законі пропонується закріпити принцип, за яким рада громади в межах закону матиме право вільно вирішувати будь-яке питання, яке не вилучене зі сфери іiі компетенції і вирішення якого не доручено жодному іншому органу» [34].

Проект нової редакції закону «Про місцеве самоврядування в Україні» станом на 30.09.2020 р. передбачає визначення сфери повноважень місцевої влади за принципом субсидіарності, тобто вирішення завдань на тому рівні, на якому їх вирішення найбільш ефективне, а також визначає виключне коло повноважень державних органів до яких належать сфери: «оборони, суверенітету, державної безпеки, захисту кордону, ядерна та радіаційна безпека, державний аудит, митний контроль» та ін. [35].

В умовах політичної нестабільності, економічної та соціальної кризи, зовнішньої агресії, при проведенні децентралізації на думку О. Скрипнюка слід передбачити й бути готовими до таких викликів:

- поглиблення регіональних ідентичностей серед населення, а також сепаратистських настроїв в окремих регіонах;

- збільшення сваволі чиновників та посилення місцевих еліт, що вимагатиме більшого контролювання видатків та їх джерел надходжень;

- зростання незадоволення населення регіонів центральною 
владою, яка не матиме можливості захистити інтереси та права регіональних громад;

- небезпеки відцентрових тенденцій через зменшення контролю та відповідальності державних органів перед місцевими адміністративно-територіальними суб'єктами [4, с. 3]. Всі ці виклики, потребують мобілізованої державної політики захисту національних інтересів, реформування судової та правоохоронної систем, забезпечення верховенства закону в об'єднаних громадах, гнучких рішень щодо національної, мовної та культурної ідентичності.

Невідворотність покарання $\epsilon$ необхідним стримуючим чинником, який повинен запобігати сепаратистським діям органів місцевої влади. В разі голосування та ухвалення рішення місцевою радою, спрямованого на порушення конституційного ладу та сепаратизм, повинна настати персональна відповідальність кожного депутата причетного до таких дій [24].

На нашу думку наразі існує ризик посилення політичних монополій, а також безконтрольних та незаконних дій місцевої влади, особливо враховуючи політичну нестабільність, зовнішню гібридну агресію, маніпуляцію суспільною думкою у процесі виборів до місцевих об’єднаних територіальних громад.

На прикладі Донецької, Луганської області та Автономної Республіки Крим, ми бачимо посилення місцевих еліт та узурпацію ними влади, а також спробу відмежуватися від центральної влади України що відбувалося на протязі десятиліть. У зв’язку з цим виникає загроза сепаратизму. Загалом Донбас залишається регіоном у якому послаблення українського культурного середовища, вплив місцевих еліт є серйозним фактором для загострення можливості сепаратистських настроїв та відцентрових тенденцій.

Саме тому, децентралізація не повинна призводити до утворення окремих відмежованих регіонів, що $є$ актуальним і для інших областей України. За часів радянської влади відбувався значний вплив русифікації Донбасу, який був викликаний постійним переміщенням росіян, що були направлені для праці, створюючи дрібноурядовий, ремісничий, купецький і робітничий прошарки. 
[13]. Частка школярів, що навчалися українською мовою у школах в 1991 р. від загальної кількості становила 3,3 \% у Донецькій та 6,7 \% в Луганській області що відображено на рис. 1.

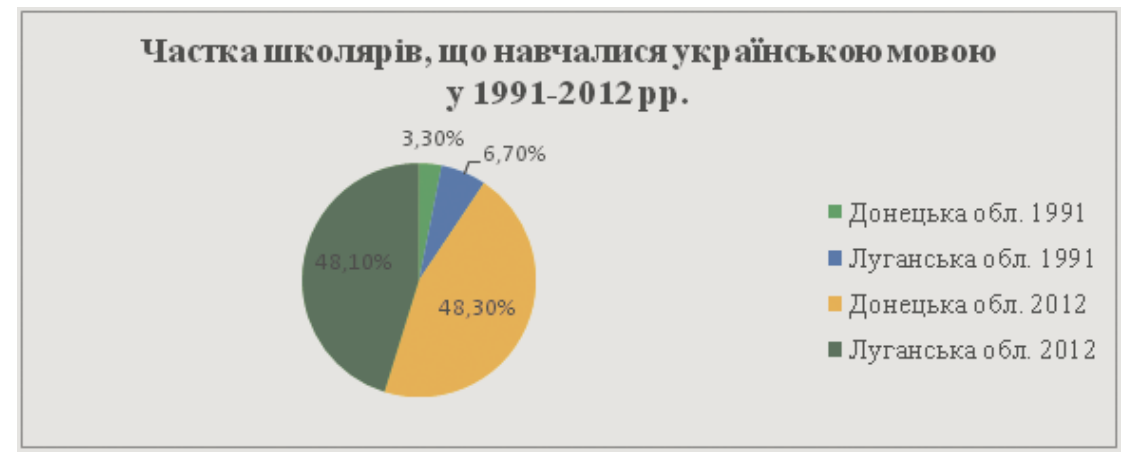

Puc. 1. Частка школярів що навчалась української мовою у період 1991 та 2012 роках

Що стосується кількості російськомовних шкіл то за період 3 1991 по 2012 р. їх кількість значно зросла до 48,3 та 48,1 відповідно у 2012 р. 32014 року кількість російськомовних шкіл в Україні значно зменшилася з 621 у 2014-2015 рр., до 194 у 2018-2019 рр. відповідно, це зображено на рис. 2.

Кількість р осійськомовних шкіл в Укр айні у 2014 2019 pp.

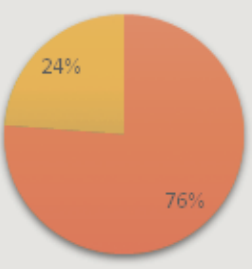

=2014-2015 pp. $\quad=2018-2019 \mathrm{pp}$

Puc. 2. Кількість російськомовних шкіл у період 2014-2015 та 2018-2019 роках 
Цікавим нам видається той факт що Кримський півострів, був єдиним регіоном, де тривалий час українських шкіл не було взагалі, при цьому українці складали чверть населення Криму поряд 3 росіянами, кримськими татарами та ін. Усі народності Криму вимушені були віддавати дітей в російськомовні школи, оскільки інших на Кримському півострові ще практично не було. Станом на 2012 рік в українських школах Криму 8\% учнів отримували освіту українською мовою.

За даними моніторингу Кримської правозахисної групи у 20182019 рр. серед двух шкіл заявлених як українські, класи з навчанням українською мовою навчання діють тільки в Симферопольській академічній гімназії. Гімназії № 11 ім. К.Тренева м. Симферопіль, викладають українську мову як факультативну, а навчання 3 усіх дисциплін проводилось виключно російською мовою. Як висновок, зазначається, що у Криму не залишилося жодної школи 3 україномовним навчанням по всім дисциплінам [14].

Принагідно зауважимо що питання мовної та етнонаціональної політики в контексті децентралізації $є$ надзвичайно важливим. Відповідно до Закону України «Про добровільне об'єднання територіальних громад», об'єднання громад відбувається на історико-культурних засадах, з урахуванням етнічних та природних чинників їх формування, що мають вплив на соціально-економічний стан [5].

У процесі об’єднання громад виникають соціокультурні виклики міжкультурної взаємодії різних етнічних груп громад. Громади багатьох регіонів мають етнонацональну специфіку та містять населення, яке складається з представників однієї або декількох різних етнічних груп. Об'єднання громад 3 такими національними меншинами може призвезвести до анклавізації об'єднаних громад, загострити актуальне питання міжкультурної взаємодії або призвести до майбутніх конфліктних ситуацій. [6, c. 16-17].

В Україні проживає чимало національностей в різних регіонах. Найбільше представників етнічних меншин проживає в Одеській, Чернівецькій та Закарпатській областях. Об'єднання 
громад 3 моноетнічним населенням, більшість 3 якого є етнічні меншини (болгари, молдовани, румуни, угорці, гагаузи та ін.), або представників різних етнічних груп є неминучим процесом. Однак, у зв'язку з цим, можливий ризик загострення міжетнічних конфліктів та навіть сепаратизму, особливо, враховуючи, сторонній вплив різних політичних сил, як в середині держави, так і представників інших держав, використаний у політичних цілях.

Голова Асоціації сприяння самоорганізації населення О. Колесников вважає: «Ризики можуть виникнути лише в моноетнічних районах та й то за умови активного зовнішнього впливу. Створення районів за етнічним принципом є недоцільним та не має сенсу. За новим баченням уряду на місцях не буде представницьких органів, а тільки префект. Префект є особою призначуваною згори, а тому сепаратизм громад у принципі неможливий. У той же час, саме громада, здатна забезпечити збереження етнічної самобутності жителів, реалізацію їх прав, таким чином попереджуючи зародження сепаратистських настроїв» [25].

В сучасному світі більшість держав $€$ поліетнічними, на території яких проживають представники інших народностей. Глобалізаційні зміни призводять до того, що держави стають все менш однорідними за своїм етнічним складом. Між представниками різних етнічних та національних груп залишаються та часто посилюються мовні, культурні чи релігійні протиріччя, які можуть призводити до суперечок та конфліктів в тому числі сепаратизму i терактів $[18$, с. 2]. Існує чимало прикладів в історії проголошення нової держави різними сепаратистськими рухами або етнічними групами. Таким прикладом є зокрема, розпад Югославії та утворення нових незалежних держав на іiі території.

Незважаючи на певні протиріччя навколо статусу та застосування української мови, однозначною думкою в контексті мовної політики є єдина державна українська мова в Україні.

Питання мовної політики в об'єднаних громадах пов'язане 3 існуванням в них власного мовного середовища певної етнічної групи (наприклад угорськомовного населення у Закарпатті чи румунськомовного в Одеській області). Відповідно до перепису 2001 
року представники румунської національної меншини становлять 151 тис. або 0,35 \% загальної чисельності населення України та зосереджені переважно в Одеській, Закарпатській і Чернівецькій областях [28, с. 11].

Можливість вивчати та спілкуватися цими мовами $є$ правом цих національних меншин але в той же час статус української мови як державної повинен зберігатися для всіх територіальних громад на території всієї України. Саме тому освітнє та управлінське середовища повинні бути україномовними. Така позиція повністю відповідає Закону України «Про забезпечення функціонування української мови як державної», відповідно до ст. 12 якого, робочою мовою органів державної влади та місцевого самоврядування є державна мова, та буде сприяти стабільності та державотворенню [7].

25 квітня 2019 року Верховна Рада України прийняла закон «Про забезпечення функціонування української мови як державної». Даний закон передбачає, обов'язкове використання української мови всюди, окрім приватних розмов та релігійних церемоній [7].

16 січня 2020 року був прийнятий закон «Про повну загальну середню освіту», який передбачає, поступове збільшення навчання угорської меншини державною мовою. У початковій школі навчання проводиться угорською мовою, у 5 класі - не менше 20\% обсягу навчального часу з поступовим збільшенням до 40\% у 9 класі. 3і старшою школою повинно бути не менше $60 \%$ річного навчального часу [26].

Прийняття даних законів викликало супротив Угорщини, яка вважає, що вони порушують права угорської громади Закарпаття, зокрема на навчання угорською мовою.

Екс-міністр закордонних справ П. Клімкін зазначає, що отримувати освіту на своїх мовах є правом меншин. Отже, їхні права не мають бути обмежені, але вони повинні мати реальну можливість вивчити українську мову [23].

Венеційська комісія у своєму висновку, щодо закону про забезпечення функціонування української мови як державної, дійшла висновку про необхідність законодавчих заходів сприяння укріпленню української мови як державної. Водночас, рекомендує 
розробити закон про меншини, забезпечити захист мов меншин, дотримуючись балансу між зміцненням державної мови та мов меншин. [22, с. 32-33].

Мусимо констатувати що громади мають різну історію та самоідентифікацію. Для того, щоб новоутворені об'єднані громади гармонійно співпрацювали та розвивалися, потрібно провести пошук їхньої спільної соціокультурної основи, спільної ідентичності. У даному контексті необхідне глибоке дослідження історії, місцевих традицій, які існували ще до радянських часів.

Для запобігання роз'єднанню, сепаратизму в об'єднаних громадах, потрібно зосередитися на об’єднуючих чинниках, які здатні об'єднати громаду. Одним 3 таких чинників є культура. Слушної $є$ думка екс-міністра культури України $Є$. Нищука: «децентралізація надає можливість створення культурних центрів, хабів які об'єднують різні напрямки. Можливість об'єднати в одну групу для спільної творчості барабанщиків, гітаристів, вокалістів 3 різних сіл, селищ, міст. Таким чином, культура може дати можливість створення спільного, об'єднуючого, що буде сприяти психологічному та ментальному зближенню в громадах» [8].

На проведення децентралізації, здатна вплинути нестабільна політична ситуація пов'язана 3 протиріччям між міським головою та місцевою радою. Приналежність до різних політичних партій та політичних поглядів міського голови та більшості депутатів міської ради, здатна суттєво вплинути, або навіть завадити ефективній діяльності місцевої влади.

Автори статті вважають що вищезазначене особливо яскраво можемо спостерігати на прикладі взаємодії Миколаївського міського голови та Миколаївської міської ради.

Так за результатами місцевих виборів які відбулися 25 жовтня 2020 р. Миколаївським міським головою став представник партії «Самопоміч». Однак за результатами виборів до міської ради 354 депутатів 26 є представниками «Опозиційного блоку», до якого належав головний опонент чинного мера. Таким чином, між міським головою та більшістю у міській раді виникло політичне протистояння, яке $\epsilon$ недоречним та заважає нормальному 
функціонуванню місцевої влади та вирішенню нагальних питань.

Проблемою $є$ неузгодженість та протистояння між різними політичними силами через що, прийняття важливих рішень з питань місцевого самоврядування, шляхом голосування на сесії міської ради (такі як прийняття бюджету) стає проблемним.

Відповідно до ч. 5 ст 42 Закону України «Про місцеве самоврядування», міський голова несе персональну відповідальність за здійснення наданих йому законом повноважень. Міський голова $є$ підзвітним, підконтрольним та відповідальним перед територіальною громадою, а також міською радою [27]. В той же час, міська рада такої відповідальності не несе [9].

Політична діяльність $є$ недоцільною у місцевій владі, оскільки місцеве самоврядування повинно займатися насамперед господарськими питаннями місцевого значення, а тому, вибори до місцевих органів бажано проводити за мажоритарною системою, без участі політичних партій на місцевих виборах.

Зміни торкнулись і виборчого законодавство так 01 січня 2020 року з набуттям чинності Виборчого кодексу України, на виборах депутатів місцевих рад у поточному році були застосовані дві виборчі системи.

В містах 3 кількістю виборців до 90 тис. осіб була застосована мажоритарна система відносної більшості 3 голосуванням у багатомандатних виборчих округах для виборів місцевих рад, рад об’єднаних територіальних громад.

В містах з кількістю виборців 90 тисяч і більше осіб-пропорційна система з відкритими партійними списками для виборів депутатів обласних, міських рад і міських об'єднаних територіальних громад.

Для виборів сільських, селищних, міських голів, а також старост застосовувалася мажоритарна система відносної більшості 3 голосуванням в єдиному одномандатному окрузі. Для виборів міських голів у містах з кількістю виборців 90 тисяч і більше осіб - мажоритарна система абсолютної більшості [10].

Серед низки причин які стали гальмівними чинниками реформи авторами виділені наступні: недостатня поінформованість про реформу, законодавчі норми та процедури $є$ одним 3 
ризиків проходження реформи, відсутність достатньої кількості інформації посилює конфліктність, плутанину та не сприйняття реформи місцевими жителями. Перед формуванням об'єднаних територіальних громад, необхідно проводити роз'яснювальні роботи 3 жителями тих населених пунктів, яких торкнеться об'єднання 3 метою пояснити їм їхні права, та вплив на розвиток регіонів де вони мешкають. Без такого роз'яснення, виникає сумнів у добровільності та повному усвідомленні громадян про об'єднання громад та успіху реформи.

Одним з викликів у сфері децентралізації є брак стабільної і модернізованої інфраструктури реформи. Новоутворені об'єднанні громади постають перед численними проблемами їх функціонування та розвитку. Серед яких зокрема є розроблення проектів розвитку, кооперація між громадами, звітність діяльності громад. В процесі утворення об'єднанних громад та децентралізації, відносини 3 центральною владою зазнали суттєвих змін. Об'єднанні громади отримали фінансові ресурси, та адміністративні повноваження, які повинні бути задіяні в проектах місцевого значення для вирішення господарських питань та місцевого розвитку. При цьому, втілення цих проектів, потребує управління місцевими ресурсами, інфраструктури, підготовки належної звітності та тендерної документації.

Фінансове забезпечення місцевого самоврядування займає особливе місце в Європейській Хартії місцевого самоврядування ї. У ст. 9 зазначено, що міська влада, має право на свої власні ресурси, які використовує на свій розсуд згідно з програмою соціальноекономічного розвитку. Ефективне використання місцевих бюджетів $\epsilon$ основою та головним змістом проведення реформи децентралізації, без якого, досягнення бажаного розвитку є неможливим [11].

Фінансова децентралізація передбачає зростання фінансової спроможності громади, а також зростання місцевих бюджетів, які у 2014 р. складали 68,6 млрд. грн., 234,1 млрд. грн у 2018 р. та 471,3 млрд. грн станом на 01.04.2020 р. [42, с. 7]. На сьогоднішній день хоч і впроваджується бюджетна децентралізація, але місцеві органи ще залежать від державного бюджету. Даному явищу, на нашу 
думку, є об’єктивні і суб'єктивні фактори. До об'єктивних факторів належать: спад та недостатній рівень економічного розвитку, падіння темпів виробництва, війна, політична нестабільність, інфляція; до суб'єктивних: неефективне управління Кабінету Міністрів України, недосконала нормативно-правова база, великий рівень тіньової економіки, неурегульований фінансовий механізм, криза банківської системи.

Як зазначає Н. Македонська, фінансова децентралізаця потребує значного доопрацювання, оскільки, існують проблеми міжбюджетного фінансування:

- необхідність передачі більшого обсягу повноважень від центральних місцевим органам влади;

- неузгодженість між зобов'язаннями за видатками та їх джерелами і обсягами фінансування;

- відсутність важелів і стимулів збільшення бюджетних надходжень, а також права самостійно, прозоро, у повному обсязі здійснювати управління власними ресурсами;

недосконала інституційна та правова база міжбюджетного фінансування яка не сприяє розвитку інфраструктури регіонів та забезпеченню суспільних благ $[12$, с. 1$]$.

Реформа децентралізації $є$ складною та має як багато переваг та позитивних моментів, так і можливих ризиків, які потрібно передбачити та запобігти. Вона потребує вироблення чіткої державної політики, направленої на запобігання внутрішнім дезорганізуючим чинникам, таким як, узурпація влади місцевими елітами, сепаратизм, поглиблення регіональних ідентичностей, а також сприяння державотворчим силам, які здатні об’єднувати громади - розвиток культури та міжкультурна взаємодія у громадах.

Статус державної мови, яка є основою для всіх громад повинен зберігатися, водночас можливість вивчати та вільно спілкуватися іншими мовами $є$ правом етнічного населення громади. Для того, щоб запобігти ризику посилення корупції та забезпечення цільового використання місцевих бюджетів, об'єднані громади потребують нагляду та контролю за законністю їх рішень. Отримуючи повноваження з центру, не всі громади є готовими для ефективного 
використання бюджетних коштів та не завжди здатні забезпечити відповідну «інфраструктуру розвитку».

Об'єднані громади потребують кваліфікованих кадрів державних управлінців, які здатні забезпечити виконання покладених на них завдань. Оновлена система управління та розподілу ресурсів потребує опанування нових знань та навичок [6, с. 14].

Реформа потребує навчання та підвищення кваліфікації посадових осіб, зокрема префектів. Отже, потрібно організувати навчання у спеціальній «школі мерів», як наприклад мер нашого міста О. Сенкевич, щоб опанувати управлінські знання та навички, для того, щоб, мати майбутній результат ефективної роботи місцевого самоврядування.

Висновки. Успішне проведення децентралізації, залежить від послідовної та злагодженої роботи державних органів, громадянського суспільства та координації західних партнерів України. Децентралізація є складним процесом, який потребує гнучкої та об'єднуючої державної політики спрямованої на попередження можливих ризиків та викликів. Аналіз процесу децентралізації, свідчить про численні виклики, які можуть вплинути на сам процес проходження реформи, призвести до дезорганізації та посилення таких негативних явищ, як сепаратизм, посилення політичних монополій, відцентрових тенденцій.

Об'єднання місцевих громад на засадах спроможності та стратегіï економічного розвитку, $\epsilon$ основою ефективного функціонування громад. Розроблена нормативно-правова основа $\epsilon$ важливою передумовою проведення реформи децентралізації та потребує значного доопрацювання. Внесення змін до Основного закону, не повинно призводити до узурпації влади та наділення державних органів невластивими їм неконституційними функціями. Об'єднання територіальних громад, має відбуватися за попередньо схваленими та узгодженими перспективними планами розвитку. Система нагляду за законністю у громадах $є$ необхідним інструментом недопущення свавілля чиновників, криміналізації процесу виборів та збільшення корупції. Політична нестабільність та протистояння між різними політичними силами на місцевому 
рівні, здатні завадити як ефективності роботи місцевої влади, так і проведенню реформи децентралізації.

Об'єднання громад за спільною соціокультурною основою $€$ необхідною складовою спроможності та співіснування громад у процесі об'єднання. Громади 3 населенням в яких переважають національні меншини повинні мати всі можливості для вивчення своєї мови та культури. Водночас, правовий статус державної мови повинен зберігатися в усіх об'єднанних громадах України та бути об'єднуючим державницьким чинником для запобігання відцентровим рухам та сепаратизму.

Вважаємо що реформа децентралізації повинна мати інформаційний супровід, для своєчасного інформування жителів громад перед їх об'єднанням, а також, пояснення їм їхніх прав та суті проведення реформи. Забезпечення об'єднанних громад професійними та висококваліфікованими державними службовцями $\epsilon$ важливою складовою ефективного проходження реформи.

Для успішного завершення реформи необхідні спільні зусилля державних органів, громадських організацій, органів місцевого самоврядування для вироблення стратегії та бачення реформи, а також виявлення і вчасного реагування на наявні ризики та виклики для попередження негативних тенденцій та явищ, які можуть загрожувати самій державності України та ефективності й спроможності об’єднаних територіальних громад.

\section{Стаття надійшла до редакції: 16.11.20}

\section{THE RISKS OF DECENTRALIZATION REFORM AND THE METHODS OF SOLVING THEM}

Volodymyr Yemelyanov, Doctor of Sciences in Public Administration, Professor, Institute of Public Administration, Petro Mohyla Black Sea National University, Mykolaiv, Ukraine.

Mykhail Sokyrco, Postgraduate student at the Institut of Public Administration, Petro Mohyla Black Sea National University, Mykolaiv, Ukraine. 
The article is devoted to analyzing the possible risks of decentralization reform and finding ways to address and reduce them. Being in the unfinished stage, decentralization is an important systemic reorganization that consecuent the security, development and economic recovery at the local and national levels. Systemic changes at the local level in times of economic and political instability require careful and prudent public policy. The main risks that threaten the reform and the danger of Ukraine's sovereignty, separatism, centrifugal tendencies, enclave, criminalization have been identified. Particular risk is the possible separatism in certain regions of the state. The volatile political situation, both at the national and especially at the local level, threatens to reform decentralization and local government performance. The questions of linguistic and ethnonational factors and their role in the formation of united communities are investigated. The methodological and regulatory arrangements for decentralization are important and relevant to the realities of community association. The proposed amendments to the Constitution of Ukraine regarding decentralization and their risks are analyzed. Legality and the rule of law are a prerequisite for preventing the risks of decentralization and for the development of united communities. The role of prefects in overseeing the legality of decisions of local self-government bodies with the possibility of violation of the functional balance of the judicial branch is considered. Possible preventive ways of reducing the risks and challenges of reform, addressing topical reform issues, and promoting state-building are suggested. The article explores the linguistic issue of national minorities and expresses the opinion on the importance of the national language as a unifying and state-building factor.

Keywords: decentralization, disorganization, supervision, effectiveness, disadvantages, risks, prefect, culture, ethno-national, language, law, minorities.

\section{Received: 16.11.20}




\section{References}

1. Taracenko, T.M. (2014). Problema dezentralizacii v reformuvanni miscevogo samovryaduvannya $\mathrm{v}$ Ukraini. [The problem of decentralization in the reform of local self-government in Ukraine]. Derzhavne upravlynnia ta mistseve samovryaduvannia-Public administration and local self-government, 2 (21) [in Ukrainian].

2. Postanova Verkhovnoi Rady Ukrainy pryiniata 31.08.2015 roku No 656-VIII, «Pro poperedne shvalennya zakonoproectu pro vnesennya zmin do Konstytuzii Ukrainy shodo dezentralizacii vlady. [Resolution of the Verkhovna Rada of Ukraine of 31.08.2015 on the preliminary approval of the Bill amending the Constitution of Ukraine on decentralization of power]. zakon.rada.gov.ua. Retrieved from https://zakon.rada.gov.ua [in Ukrainian].

3. Yemelyanov, V.M., \& Shulga, A.A. Normatyvno-pravove zabezpecennya reformuvannya miscevogo samovryaduvannya ta objednannya terytorialnyh gromad v Ukraini [Legal support for reform of local self-government and unification of territorial communities in Ukraine]. Naukovi praci. Derzhavne upravlinnya - Scientific works. Governance [in Ukrainian].

4. Skrypnyuk, O. Detsentralizaciya vlady yak chynnyk zabezpecennya stabylnosti kostytutsiynogo ladu: teoriya i praktyka [Decentralization of power as a factor in ensuring the stability of the constitutional order: theory and practice]. Naukova biblioteka - Scientific Library [in Ukrainian].

5. Pro dobrovilne objednannya terytorialnyh gromad. Zakon Ukrainy pryinyatyi 05.02.2015 r. Vidomosti Verkhovnoi Rady 2015, No 13, st. 91 [About voluntary association of territorial communities. Law of Ukraine dated 05.02. 2015 Verkhovna Rada Notices 2015, No 13, p.91]. zakon.rada.gov.ua. Retrieved from https://zakon.rada.gov.ua [in Ukrainian].

6. International Alert Dezentralizatsiya $\mathrm{v}$ Ukraini dosyagnennya, nadii i pobouvannya/ Ukrayinskyi nezalezhnyi tsentr politychnyh doslidzen [International Alert Decentralization in Ukraine of achievement, hope and fear] [in Ukrainian].

7. «Pro zabezpechennia funktsionuvannya ukrainskoi movy yak derzhavnoi». Zakon Ukraini pryiniatyi 25.04.2019 r. Vidomosti Verkhovnoi Rady, 2019 No 21, st. 81. [On ensuring the functioning of the Ukrainian language as a state language. Law of Ukraine 2015 Verkhovna Rada Notices dated 25.04.2019]. zakon.rada.gov.ua. Retrieved from https://zakon.rada.gov.ua [in Ukrainian]. 
8. Cultura v umovah dezentralizacii: comentari. [Decentralization Culture: Comments]. decentralization.gov.ua. Retrieved from: https://decentralization.gov.ua/news/11128 [in Ukrainian].

9. «Pro misceve samovryaduvannya». Zakon Ukraini pryiniatyi 20.05.1997 roku No 24. Vidomosti Verkhovnoi Rady 1997, [About local government. Law of Ukraine 20.05.1997 Verkhovna Rada Notices]. zakon.rada. gov.ua. Retrieved from https://zakon.rada.gov.ua [in Ukrainian].

10. Vyborchyi kodeks Ukraini pryiniatyi 19.12.2019 roku Vidomosti Verkhovnoi Rady 2020, No 396-IX. [The Electoral Code of Ukraine dated 19.12.2019 Verkhovna Rada Notices]. zakon.rada.gov.ua. Retrieved from https://zakon.rada.gov.ua [in Ukrainian].

11. Europeiska Hartiya miscevogo samovryaduvannya vid 15 zhovtnya 1985 roku.// Oficiyniy visnyc Ucraini vid 03.04.2015 roku. Vidomosti Verkhovnoi Rady Ukrainy vid 16.11.2009 [European Charter of Local Self-Government of 15 October 1985. // Official Bulletin of Ukraine dated 03.04.2015. Information of the Verkhovna Rada of Ukraine from 16.11.2009] [in Ukrainian].

12. Korneva, O.V. Osnovni problemy provedennya reformy decentralizacii v Ukraini u 2014-2018 [The main problems of decentralization reform in Ukraine in 2014-2018] [in Ukrainian].

13. Chastka uchniv u shcolah Ukraini, shcho navchautsia ukrainskoyu [Share of students in Ukrainian schools studying Ukrainian]. statistika.in.ua. Retrieved from http://statistika.in.ua/mova2001/ukrainska_v_shkolah [in Ukrainian].

14. V Krimu ne ostalos ne odnoi shkoly z ukrainskim yazikom obucheniya [There are no schools with the Ukrainian language of instruction left in Crimea]. crimeahrg.org. Retrieved from https://crimeahrg.org/ru/v-krymu-ne-ostalos-niodnoj-shkoly-s-ukrainskim-yazykom obucheniya [in Ukrainian].

15. Kvitca, S.A. Prinzip subsidearnosti ta protsesy dezentralizazii v Ukraini [The principle of subsidiarity and processes of decentralization in Ukraine]. Aspecty publichnogo upravlinnya - Aspects of public administration [in Ukrainian].

16. «Pro zatverdzhennya metodycy formuvannya spromozhnyh teritorialnyh gromad». Postanova Kabinetu Ministriv 08.04.2015 [About the consolidation of the methodology for the formation of adjoining territorial communities of Resolution of the Cabinet of Ministers vid 04.04.2015 year, number 214]. zakon.rada.gov.ua. Retrieved from https://zakon.rada.gov.ua [in Ukrainian]. 
17. Ibragimova, A.A. (2015). Haracterystyca normatyvno-pravovoi basy derzhavnoi polityky u sferi pobudovy spromozhnyh teritorialnyh gromad $v$ Ukraini [Characteristics of the regulatory framework of sovereign politics in the sphere of incentive of territorial communities in Ukraine Naukovi praci. Derzhavne upravlinnya - Scientific works. Governance] 263, Vol. 252 165-173 [in Ukrainian].

18. Andryash, V.I. (2013). Secesiya v suchasnomu sviti: ryzici i zagrozy dlya Ukraini [Secession in the modern world: risks and threats to Ukraine] Retrieved from http://lvivacademy.com/vidavnitstvo_1/visnik11/fail/Andrijash. pdf [in Ukrainian].

19. Bezsmertnyi: Dezentralizaciya tse ne reforma. [Bessmertnyi: Decentralization is not reform]. www.facebook.com. Retrieved from https://www. facebook.com/bezsmertnyi/videos/\%D0\%B1\%D0\%B5\%D0\%B7\%D1\%81 $\%$ D0\%BC\%D0\%B5\%D1\%80\%D1\%82\%D0\%D1\%80\%D0\%B5\%D1\%84 $\% \mathrm{D} / 2105463063037269 /: 22.11 .2019$ [in Ukrainian].

20. Zakon Ukrainy Pro vnesennya zmin do zakonu Ukraini «Pro dobrovilne objednannya teritorialnyh gromad» shodo sprozhennya procedury zatverdzhennya perspectyvnyh planiv formuvannya teerytoriy gromad Avtonomnoi Respublicy Crym, oblastey pryiniatyi 5 grud, 2019 roku No 348-IX [Law of Ukraine on Amendments to the law of Ukraine on voluntary unification of territorial communities concerning simplification of the procedure for approval of prospective plans for the formation of territories of communities of the Autonomous Republic of Crimea, oblasts, accepted 5 December 2019 year No 348-IX]. zakon.rada.gov.ua. Retrieved from https://zakon.rada.gov.ua [in Ukrainian].

21. Proect zmin do Konstitucii $\mathrm{v}$ chastini dezentralizacii potribno obgovoryuvaty z predstavnycamy miscevogo samovryaduvannya - Asotsiatsiya obyednanyh terytorialnyh gromad. [The draft amendments to the Constitution regarding decentralization should be discussed with the representatives of local self-government - the Association of united territorial communities]. uacrisis. org. Retrieved from http://uacrisis.org/ua/74409-proyekt-zmin-konstitutsiyiasotsiatsiya-otg 29.11.2019 [in Ukrainian].

22. Vysnovok shodo zakonu pro zabezpechennya funkcionuvannya ukrainskoi movy yak derzhavnoi pryjnyatyj Venetsianskoyu Komisiyeyu na 121-mu plenarnomu zasidanni (Venecia, 6-7 grudnya 2019) Vysnovok No 960/2019 [Opinion on the Law on Ensuring the Functioning of the Ukrainian Language as 
State adopted by the Venice Commission at the 121st Plenary Session (Venice, December 6-7, 2019) Opinion No 960/2019] [in Ukrainian].

23. Klimkin obgovoryt «movnyi zakon» z glavoyu MZS Ugorchchyny [Klimkin will discuss the "language law" with the Hungarian Foreign Minister]. www.unian.ua. Retrieved from https://www.unian.ua/politics/10532160-klimkin-obgovorit-movniy-zakon-z-glavoyu-mzs-ugorshchini.html [in Ukrainian].

24. Ruslan Rohov: Decentralizacija maje peretvoryty «piddanyh derzhavy» na yii «akcioneriv». [Ruslan Rohov: Decentralization should turn «subjects of the state» into Its «shareholders»]. agropolit.com. Retrieved from: https://agropolit.com/interview/690-ruslan-rohov-detsentralizatsiya-maye-peretvoritipiddanih-derjavi-na-yiyi-aktsioneriv [in Ukrainian].

25. Etnichnyy factor ne stoit na zavadi obyednannyu gromad. Resultaty doslidzhennya [Ethnicity does not hamper community reunification. Research results]. decentralization.gov.ua. Retrieved from https://decentralization.gov. ua/news/11970 [in Ukrainian].

26. Zakon Ukraini Pro zagalnu serednyu osvitu vid 16.01.2020, No 0901 [Law of Ukraine on General Secondary Education of 16.01.2020, No 0901]. zakon.rada.gov.ua. Retrieved from https://zakon.rada.gov.ua/laws/show/651-14 [in Ukrainian].

27. Rishennja Konstytuciynogo Sudu Ukraini u spravi za konstituciynim podannyam 49 narodnyh deputativ Ukraini I vykonavchogo comitetu Vinnytskoi miskoi rady shodo oficiynogo tlumachennja pologen' statey 38, 78 Konstytutsii Ukraini, statey 1, 10, 12, chastyny drugoi statti 49 Zakonu Ukraini «Pro misceve samovrjaduvannya v Ukraini» (sprava pro sumisnyctvo posad narodnogo deputata Ukraini i miskogo golovy). [Decision of the Constitutional Court of Ukraine in the case on the constitutional submission of 49 People's Deputies of Ukraine and the executive committee of the Vinnytsia city council on the official interpretation of the provisions of Articles 38, 78 of the Constitution of Ukraine, articles 1,10,12, part two of article 49 of the Law of Ukraine "On Local Self-Government in Ukraine" (the case of combining the posts of people's deputy of Ukraine and the mayor)]. zakon.rada. gov.ua. Retrieved from https://zakon.rada.gov.ua/laws/show/v007p710-99 [in Ukrainian].

28. Tyshchenko, U.A. Rumunska ta moldovska natsionalni menshyny $\mathrm{v}$ Ukraini: stan, tendentsiyi ta mozhlyvosti spivpratsi [Romanian and Moldovan national minorities in Ukraine: status, trends and opportunities for cooperation]. 
Nationalnyi institute strategichnyh doslidzhen zb. naucovo - ekspertertnyh materialiv - National Institute for Strategic Studies, collection of scientific and expert materials [in Ukrainian].

29. Evtushenko, O.N. \& Andriyash, O.I. Chornomorska obyednana terytorialna gromada Mykolaivskoi oblasti v umovah decentralizatsii [The black sea unit territorial community of the Mykolaiv region in decentralization conditions]. Naukovi pratsi. Derzhavne upravlinnya - Scientific works. Governance [in Ukrainian].

30. Oblasti mayut actualizuvaty perspectyvni plany formuvannia teritoriy [Areas should update prospective plans for territorial formation]. www.kmu.gov. ua. Retrieved from https://www.kmu.gov.ua/news/oblasti-mayut-aktualizuvatiperspektivni-plani-formuvannya-teritorij [in Ukrainian].

31. Proekt Zakonu nomer 2598 vid 13.12.2019 «Pro vnesennia zmin do konstytutsii Ukraini shchodo dezentralizatsiyi vlady» [Draft Law number 2598 of December 13, 2019 On Amendments to the Constitution of Ukraine concerning the decentralization of power]. zakon.rada.gov.ua. Retrieved from https:// zakon.rada.gov.ua [in Ukrainian].

32. Zakon Ukrainy «Pro derzhavne reguluvannia diyalnosti shchodo organizatsii ta provedennia azartnykh igor»: pryiniatyi 14 lypnia 2020 r. No 768 - XI // Vidomosti Verkhovnoi Rady [Law of Ukraine On State Regulation of Activities Concerning the Organization and Conduct of gambling adopted on july 14, 2020 No 768 - XI Information of the Verkhovna Rada of Ukraine]. zakon.rada.gov.ua. Retrieved from https://zakon.rada.gov.ua [in Ukrainian].

33. Yak zrobyty mistsevu vladu prozorishoyu [How to make the local government more transparent]. ti-ukraine.org. Retrieved from https://ti-ukraine. org/wp-content/uploads/2017/12/anatitychnyy-zvit_prozorist.pdf [in Ukrainian].

34. Sayt Novyn Poltavshchyny [Poltava region news site]. np.pl.ua. Retrieved from https://np.pl.ua/2020/05/na-poriadku-dennomu-detsentralizatsiichitke-rozmezhuvannia-povnovazhen-v-iacheslav-nehoda/ [in Ukrainian].

35. Zakon Ukrainy «Pro vnesennya zmin do Zakonu Ukraini Pro mistsevi derzhavni administratsiyi» ta deyakyh inshyh zakonodavchyh aktiv Ukrainy shchodo dezentralizatsiyi ta rozmezhuvannia povnovazhen iz organamy mistsevogo samovryaduvannia» : proekt stanom na 30.09.20. Vidomoosti Verkhovnoi Rady [Law of Ukraine On amendments to the law of Ukraine on local state administrations and certain other legislative acts of Ukraine on decentral- 
ization and separation of powers with local self-government bodies: draft as of 30.09.20 Information of the Verkhovna Rada]. zakon.rada.gov.ua. Retrieved from https://zakon.rada.gov.ua [in Ukrainian].

36. Oleksiy Chernyshov: Osnovnyi etap reformy administratyvnoterytorialnogo ustroyu zavershuyetsya [Oleksiy Chernyshov: The main stage of the reform of the administrative-territorial system is coming to an end]. decentralization.gov.ua. Retrieved from https://decentralization.gov.ua/ news/12491 [in Ukrainian].

37. Zakon Ukrainy «Pro spivrobitnytstvo terytorialnykh hromad» [Law of Ukraine «On Cooperation of Territorial Communities»]. zakon.rada.gov.ua. Retrieved from http://zakon.rada.gov.ua/laws/show/1508-18. [in Ukrainian].

38. Zakon Ukrainy "Pro zasady derzhavnoi rehionalnoi polityky» [Law of Ukraine «On the Principles of State Regional Policy»]. zakon.rada.gov.ua. Retrieved from http://zakon.rada.gov.ua/laws/show/156-19 [in Ukrainian].

39. Zakon Ukriny «Pro ratyfikatsiyu Dodatkovogo protokolu do Yevropeiskoi hartii mistsevogo samovryaduvannia pro pravo uchasti u spravah organu mistsevogo samovriaduvannia» pryiniatyi 02 sep. 2014 roku No 1664 VII [Law of Ukraine on ratification of the Additional protocol to the European charter of local self-government on the right to participate in the affairs of local self-government bodies]. zakon.rada.gov.ua. Retrieved from http://zakon.rada. gov.ua [in Ukrainian].

40. Zakon Ukrainy «Pro vnesennia zmin do Biudzhetnoho kodeksu Ukrainy shchodo reformy mizhbiudzhetnykh vidnosyn» [The Law of Ukraine «On Amendments to the Budget Code of Ukraine on the Reform of Intergovernmental Fiscal Relations»]. zakon.rada.gov.ua. Retrieved from http:// zakon. rada. gov.ua/laws/card/79-19 [in Ukrainian].

41. Zakon Ukrainy «Pro vnesennia zmin do Podatkovoho kodeksu Ukrainy ta deiakykh zakonodavchykh aktiv Ukrainy shchodo podatkovoi reformy» [The Law of Ukraine «On Amendments to the Tax Code of Ukraine and Certain Legislative acts of Ukraine on tax reform»]. zakon.rada.gov.ua. Retrieved from http:// zakon4.rada.gov.ua/laws/show/71-19 [in Ukrainian].

42. Evtushenko, A. \& Popova, T. \& Samsonyuk, A. (2018). Stanovlennia instytutu mistsevoho samovriaduvannia yak detsentralizovanoi publichnoi munitsypalnoi vlady terytorialnykh hromad v Ukraini: teoriia ta praktyka [Construction of the local self-government institute as decentralized public municipal authority of territorial communities in Ukraine: theory and practice] 
Publichne upravlinnia ta rehionalnyi rozvytok - Public Administration and Regional Development, (2), 296-321. https://doi.org/10.26693/pard2018.02.296. Retrieved from: https://pard.mk.ua/index.php/journal [in Ukrainian].

43. Shtyrov, O. \& Hirzhev, A. (2019). Realizatsiia mekhanizmiv derzhavnoi pidtrymky rehionalnoho rozvytku na prykladi Mykolaivskoi oblasti [Implementation of mechanisms of the state support of regional development on an example of the Nikolaev area]. Publichne upravlinnia ta rehionalnyi rozvytok - Public Administration and Regional Development, (5), 645-668. https://doi.org/10.34132/pard2019.05.09 Retrieved from: https://pard.mk.ua/ index.php/journal [in Ukrainian].

\section{Відомості про авторів / Information about the Authors}

Смельянов Володимир Михайлович: Чорноморський національний університет ім. Петра Могили: вул. 68 десантників 10, Миколаїв, 54003, Україна.

Volodymyr Yemelyanov: Petro Mohyla Black Sea National University: 68 Desantnykiv str. 10, Mykolaiv, 54003, Ukraine.

\section{ORCID.ORG/0000-0002-2995-8445}

\section{E-mail: d idu@ukr.net}

Сокирко Михайло Степанович: Чорноморський національний університет ім. Петра Могили: вул. 68 десантників 10, Миколаїв, 54003, Україна.

Mikhail Sokirko: Petro Mohyla Black Sea National University: 68 Desantnykiv str. 10, Mykolaiv, 54003, Ukraine.

ORCID.ORG/ 0000-0002-0479-5301

\section{E-mail: mihaillite014@gmail.com}

